\title{
INNOVATIVE PROGRAM FOR DETERMINATION OF INDIVIDUAL DISCREDIT
}

\section{Najmidinova Nilufar}

The Republican Center Of Forensic Examination Named After X. Suleymanova Document Forensics Laboratory Expert, Uzbekistan

\section{ABSTRACT}

Today, serious attention is being paid to the practical significance of language, how easily and fairly it solves problems in human life. This article deals with the cases of discrediting a person and his linguistic examination, the circumstances in which a person is discredited, its linguistic and legal basis, as well as the role of linguists and jurists in ensuring the inviolability of the honor, dignity and dignity of every member of society. thought about.

KEYWORDS: - Linguistics, jurisprudence, logic, analytics, linguistic expertise, personality, slander, slander, embarrassment, shame, false message.

\section{INTRODUCTION}

Valuable researches are being conducted in the world to increase the practical significance of language, to study in depth its role and place in human life. In particular, many positive results in the field of applied linguistics, such as computer linguistics, psycholinguistics, neurolinguistics, linguistic expertise, confirm this. Today, theoretical and practical research of similar value has begun in Uzbek linguistics. Particularly, European countries are not limited to linguistics, psychology, sociology, law, history, logic, philosophy to use linguistic expertise in court proceedings, to solve controversial crimes, especially in cases of conflict between citizens (insults, discrimination and humiliation). and high efficiency is achieved through the use of the services of professionals who have thoroughly mastered the fundamental sciences, such as mathematics. The integration of linguistics with other disciplines has intensified. In this regard, it is worth to tell that linguist B. Mengliev said, "The practical function of language has begun to work extensively in various fields of science. These factors have led to the development of a number of studies in modern linguistics. "[1].

It is no secret that the offenses and crimes that occur in most cases are committed directly through speech activities such as intimidation, fraud, coercion, bribery, insult, slander. As a result of the need to solve crimes in such cases and to reasonably conclude whether other types of activities are criminal or not, a new direction in linguistics has emerged - linguistic forensic science, which studies the relationship between language and law. Of course, while the most important aspect to be studied in linguistic expertise is the legal assessment of the content of speech, the active 
CURRENT RESEARCH JOURNAL OF PHILOLOGICAL SCIENCES 2(12):

221-226, December 2021

DOI: https://doi.org/10.37547/philological-crjps-02-12-42

ISSN 2767-3758

(C)2021 Master Journals

Crossref do

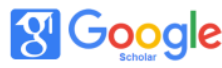

Accepted26 ${ }^{\text {th }}$ December, 2021 \& Published 31 th December, 2021

integration of different disciplines is important to achieve this goal, as noted above.

The field of forensic linguistics has emerged relatively recently in linguistics, so first of all to get acquainted with the concept of forensic linguistics, as well as to determine what tasks and methods this discipline seeks, its role in assessing Doctor of Philology, professor, M. A. Grachev's views on "forensic linguistics." The scholar distinguishes three components of the term "forensic linguistics":

1) the department of linguistics studying the text for legal purposes;

2) the department of linguistics teaching forensic linguistics;

3) the branch of linguistics that studies the sociolinguistic aspects of the criminal subculture."[2. 26].

In connection with the term lingo-forensic examination, the term "jurisprudence" or "legal linguistics" proposed by the famous scientists E. I. Galyashina, N. D. Golev in the late 1990s stands out. The content of this concept contains only two points of the definition given by M. A. Grachev. He emphasizes that knowledge of the linguistic components of a subculture can be used for practical purposes, such as identity identification, forensic examination during search operations [3.497]. Forensic linguistics regulates the identification and identification of speech material through linguistic expertise, and linguistic research belongs to the subject of "forensic speech," where language is the object of research, namely speech behaviors and speech activity the person is checked. The first linguistic investigations were conducted in the early 1990s and provided some assistance to law enforcement. However, the lack of practical experience and methodological recommendations showed that there are a number of difficulties in the examination of speech for the trial, in the positive outcome of the expected results. Of course, the work done in this regard was important as an experiment and began to yield its positive results in subsequent work.

In the era of information technology, discrediting, insulting, and copyright infringement are commonplace. For some citizens, such verbal behavior seems very convenient, anonymous, and at the same time unpunished. Although these cases require linguistic investigation, the scientific basis for drawing conclusions for such speeches, which are considered insulting, has not been sufficiently studied. Of course, because of the convenience and ease of today's media exchange, the abuse of freedom of speech necessitates the fight against insults to others, which negatively affects the powers of more government officials, as well as law enforcement and other responsible bodies. It is possible to achieve positive prospects for further development by checking and processing linguistic data in these areas. At this stage, linguistic expertise works as a way to protect an individual's dignity, honor, and dignity in resolving civil and criminal cases. The objects of linguistic examination include the products of a person's speech activity: language and speech units (phonemes, morphemes, lexemes), human thinking recorded in some material means. The practical need for linguistic expertise arises, first of all, in the process of consideration and resolution of court cases, when it is necessary to identify facts of legal significance. In the professional activity of linguists, the methods of studying the semantic meaning of language units, individual elements of words and the semantic content of the whole sentence, the process of comparing natural or linear series of lexemes are widely and actively used. The hidden meaning of the text is analyzed, contextual cues take into account the individual's speech, which allows to determine the psychological characteristics of the individual through the method of pragmalinguistic 
CURRENT RESEARCH JOURNAL OF PHILOLOGICAL SCIENCES 2(12):

221-226, December 2021

DOI: https://doi.org/10.37547/philological-crjps-02-12-42

ISSN 2767-3758

(C)2021 Master Journals

Crossref do

gil Google

Accepted26 ${ }^{\text {th }}$ December, 2021 \& Published $31^{\text {th }}$ December, 2021

analysis, methods are applied and this includes determining the genre features of the text, methods of decoding the text and so on. Linguistic expertise as one of the most difficult and time-consuming types of forensic examination is a task that can be solved only with the involvement of qualified specialists with specialized knowledge in the field of linguistics, lexicography and stylistics from a linguistic point of view.

Linguistic expertise has become widely used in practice due to the emergence of many claims related to the protection of honor, dignity, business (professional) reputation. Research is assigned when it is not possible to obtain relevant information by other means. In this case, it will be one of the sources of evidence. One of the new directions in the field of applied linguistics is the semantic expertise used in recent decades.

In the 5-volume explanatory dictionary of the Uzbek language, it is written: "Обрў(Й)сизлантирмоқ Обрўйсиз қилмоқ, обрўйига путур етказмоқ. Бўтани обрўсизлантириб, аёлларни колхоздан бездириш кимга зарур экан? С. Ахмад, Хукм.

Беобрў қилмоқ Обрўсини тўкмоқ. Халойиқ олдида мени беобрў қилишинг оқибатини.. бир кўрсатиб қўяй хали. М. Исмоилий, Фарғона т.0."[4.76]

Semantic expertise is performed to determine and correctly determine the meaning of a speech activity, to determine the emotional value in a particular statement, to identify negative information, to analyze the semantic core, and to identify all possible lexical meanings, to determine consistency and adequacy in speech. In addition, semantic expertise is used by an expert in this profile in the investigation of cases of terrorism, slander and insult, protection of honor, dignity, business reputation, patent and copyright disputes. A highly responsible specialist linguist should undergo advanced training in linguistics. The specialist must have extensive knowledge, observation, analytical thinking, good memory and a high level of concentration, accuracy and hard work. In the process of training specialists with professional knowledge in linguistics, special attention is paid to the study of disciplines of linguistics, such as lexical and linguistic semantics. In the process of mastering these disciplines, future linguists study the normative (dictionary) meanings and meanings of individual words, phrases, sentences, pieces of text. In order to acquire specialized knowledge in the field of linguistics, it is important for professionals to get acquainted with and study the section of the subject of "linguistic pragmatics", which determines the communicative and motivational direction of statements expressed in the form of calls to something. Also, the expert linguist must have knowledge in the field of rhetoric, because in conducting research, the specialist must know the mechanisms of interpretation of reality, methods of controlling the consciousness of the addressee, the mechanisms of understanding speech messages. Thus, special knowledge is required in the linguistic sciences, which helps to identify the various clear and personal information and other important information of the negotiators from the speech message [5.27].

Discredit of a person is usually in the form of slander. In uzbek explanatory dictionary "Тухмат [а.- айблаш, айблов] 1 Бировни айблаш ёки қоралаш мақсадида ўйлаб чиқарилган асоссиз даъво; бўхтон. Тухмат қилмоқ. Тухмат ёғдирмоқ. Тухмат тош ёради, Тош ёрмаса, бош ёради. Мақол. -Нега эрингга хат ёзмайсан? -Вой бундан бўлак хам тухмат борми? Нега хат ёзмас эканман. А. Қаххор, Хотинлар. Уйинг куйгурда икки ой қадар ишладим. Кейин хайдади. Бошимга қанча тухматлар ортди яна. Ойбек, Танланган асарлар." 2 с. т. Ортиқча ташвиш, 
CURRENT RESEARCH JOURNAL OF PHILOLOGICAL SCIENCES 2(12):

221-226, December 2021

DOI: https://doi.org/10.37547/philological-crjps-02-12-42

ISSN 2767-3758

(C)2021 Master Journals

Crossref do

gil Google

Accepted26 ${ }^{\text {th }}$ December, 2021 \& Published 31 th December, 2021

дардисар. Шошиб турганимда, сен хам тухмат бўлдинг менга. Хизматга тухмат с. т. Кимсага хизмат, яхшилик қилиб, охири айбдор бўлиб қолиш ёки ўзига ташвиш, дардисар орттириш; яхшиликка ёмонлик. ...”[6.226] тарзида берилган. However, it cannot be said that defamation is done only by slander. For example, if a person has a marital problem, for example, does not talk to his parents, or discloses information that is secret to the public, such as his illegal marriage and having children from that marriage, it will discredit that person. According to Article 27 of the Constitution of the Republic of Uzbekistan, "Everyone has the right to protection against encroachment on his honor and dignity, intrusion into his private life and inviolability of his home [7]. No one shall be subjected to arbitrary interference with his privacy, family, home or correspondence, nor to attacks upon his honor and reputation. marked as In such cases, it is no exaggeration to say that the prohibition to interfere in the life of a person, except in places permitted by law, and to disseminate information that should be kept confidential, is intended to prevent defamation of those persons. Depending on the form of the defamatory expressions, the means of expressing those expressions in writing and orally can be divided into verbal and nonverbal. In the explanatory dictionary of the Uzbek language, the first meaning of the word accuse is to find guilty, to accuse. The legal meaning is to prosecute. Ўша вақтларда махаллий рахбарларни айблашга бахона топилмай қолганда, уларнинг фарзандлари ва қариндош-уруғларини тухмат билан қамашарди. Газетадан." In the second sense, convicting and disseminating a crime to the general public without proving that a criminal act has been committed has not yet been proved. Dissemination of such information is primarily prohibited by law and may result in the discrediting of the person who disclosed it to the public as a result of factors such as personal attitude and level of knowledge. In such cases, a detailed study of the event at the time and place where that information was disseminated is required. We can also give an example of distributing the speech space that someone else is saying as a quote. After all, the linguist B. Mengliev's opinion that there is nothing more abstract than a piece of text is correct and appropriate. Although the Uzbek dictionary does not comment on the word Shame, in this case it is understood to declare someone's mistakes and shortcomings in front of others. On the contrary, it is not disrespectful to tell a person about a mistake or shortcoming in a non-judgmental way. This is confirmed by the proverb, "Дўст айбингни яшириб, душман тошириб айтар". Also in the explanatory dictionary of the Uzbek language Шарманда [ф. - виждонли, инсофли; уятчан; уятга қолган, изза бўлган] Шарму хаёни йўқотган; хаёсиз. У ахлоқсиз бир кимса-ку! У бехаё, шарманда. К. Яшин, Хамза. Шарманда бўлмоқ Нихоятда уятга қолмоқ; шармандаси чиқмоқ. Шундай қилайликки.. пинхона харакатлари хам фош бўлиб, ўзлари эл орасида шарманда бўлсинлар. Газетадан. Шарманда қилмоқ Нихоятда уятли холатга қўймоқ. Нега мени шунча одам олдида шарманда қиласан, жодугар! ў. Хошимов, Қалбингга қулоқ сол."[8.548]. That is, a person whose mistake or guilt has been exposed in public, a person of disrepute. Insulting sentences are often used to discredit a person. An explanatory dictionary of the Uzbek language reads: -Ия, ха, бошқа билан қовушдик денг, у кўзини қисиб, қизни хақоратлашга оғиз жуфтлади. Ф. Мусажон, Хури. Бу ўткинчи беш кунлик дунёда биз ёқалашамиз, қон тўкамиз, бир-биримизни хақоратлаймиз.. Мирмухсин, Меъмор.” тарзида берилган. Insults at this point may result in one or more of the following events:

1) defamation of the insulted person when someone insults someone;

2) defamation of both persons when someone 
CURRENT RESEARCH JOURNAL OF PHILOLOGICAL SCIENCES 2(12):

221-226, December 2021

DOI: https://doi.org/10.37547/philological-crjps-02-12-42

ISSN 2767-3758

(C)2021 Master Journals

Crossref do

gil Google

Accepted26 ${ }^{\text {th }}$ December, 2021 \& Published $31^{\text {th }}$ December, 2021

insults someone;

3) defamation of the person who insulted another.

In the first case, a person insults others in front of others because of another person's mistakes and shortcomings, in the second case, they insult each other because of the personal relationships of people who are noticed as partners, close friends, in the third case, regardless of their social status in society. occurs when insulting respected people who have lived and passed away. However, defamation is not done with insults alone. For example, spreading false information that a certain person has done something he did not do, or, to be more precise, claiming that an athlete has won, claiming that a person who has not been promoted but has been demoted has been promoted to a higher position.

In order to prevent the spread of false information and to prosecute those who disseminated it, the law No.-658, adopted on December 25, 2020, establishes liability for disseminating false information. In general, false reports about others can often discredit those individuals [9].

It should be noted that defamatory expressions are characterized not only by insulting words, but also by semantically positive features, but not actually confirmed.

An important condition for obtaining sound conclusions in the process of processing textual information in the implementation of linguistic expertise is the results of basic research obtained in the theory of speech communication. From the point of view of oral communication, the linguistic study of texts is the application of practical knowledge about the connections between the elements of the language system that are necessary for the legal interpretation of the meaning of the text. E.I. Galyashina defines forensic linguistic expertise as an effective procedural activity for the linguistic study of speech data (recorded in any material means) that has evidence value [10].

Knowledge of linguistics can improve the quality of law enforcement work. Linguists not only assist in the investigation of civil and criminal cases, their specialized knowledge in the field of linguistics is also necessary for other areas of society. It should be noted that a distinguishing feature of the evidence base of forensic science is the results of empirical research, rather than grounded assumptions or hypotheses that have nothing to do with applied linguistics. At the current level of development, research in the field of linguistic expertise is relevant and socially relevant. Linguistic expertise reveals the peculiarities of the application of linguistic knowledge in the field of language and law. Modern scientific research in legal linguistics is associated with the creation of new theoretical developments for the practical application of speech technologies, as well as the study of the functional characteristics of language types in the field of human activity. Research in forensic linguistics is important as an innovative program that presents the theory and methods of language use in a variety of legal contexts.

\section{REFERENCES}

1. Mengliyev B., Karimov R. Theoretical fundamentals of uzbek-english parallel corpus $\backslash \backslash$ Journal Of critical reviyewsissn- 2394-5125 vol 7, issuye 17, 2020. Bakhtiyor Rajabovich Mengliyev, Nigmatova Lolakhon Hamidovna. Problems of language, culture and spirituality in general yexplanatory dictionariyes of Uzbek language / Inernational Journal of Psychosocial Rehabilitation. ISSN: 1475-7192.

2. Shakhnoza Gulyamova, Bakhtiyor Mengliyev. Lexical-semantic classification of yeuphemisms of the feminine gender in the 
CURRENT RESEARCH JOURNAL OF PHILOLOGICAL SCIENCES 2(12):

221-226, December 2021

DOI: https://doi.org/10.37547/philological-crjps-02-12-42

ISSN 2767-3758

(C)2021 Master Journals

crossref do) :810 Google

Accepted26 ${ }^{\text {th }}$ December, 2021 \& Published 31 th December, 2021

Uzbek language // Academia Open.

consciousness

3. Vol 1. No 1. (2019): JuneArticles.

4. Грачев М. А. Современные проблемы лингвокриминалистики как науки // Вестник Череповецкого государственного университета. 2015. № 1. С. 26.

5. Annotated dictionary of the Uzbek language. 5 vols. Volume III. - Tashkent: National Encyclopedia of Uzbekistan, 2020.

6. Annotated dictionary of the Uzbek language. 5 vols. Volume IV. - Tashkent: National Encyclopedia of Uzbekistan, 2020.

7. https://www.lex.uz/docs/20596 (Ўзбекистон Республикаси Конституцияси)

8. https://lex.uz/docs/5186087

9. https://cyberleninka.ru/article/n/k-voprosuo-lingvisticheskoy-ekspertize

10. Grachev M. A. Problems of formation and formation of linguistic criminologists as science // Vestnik Nizhny Novgorod University. N. I. Lobachevskogo. 2010., 4.

11. Lobanova I. N., shchetinina Yu. S. K voprosu ob uchete natsionalno-kulturnoy spetsifiki pri lingvisticheskoy ekspertize testa // Problemy romano-germanskoy filologii, pedagogiki i metodiki prepodavaniya inostrannyx yazykov. 2012. № 9.

12. Bazylev V. N., Osadchiy M. A. «Russkiy yazyk na grani prava: funktsionirovanie sovremennogo russkogo yazyka $\mathrm{v}$ usloviyax pravovoy reglamentatsii rechi» // Yurlingvistika. 2012. № 1. S.

\section{INTERNET RESOURCES}

1. 1.https://www.researchgate.net/publication /228881331_The_UCREL_semantic_analysis_ system

2. www.ruscorpora.ru

3. http: //www.natcorp.ox.ac.uk/

4. http: //www.ruscorpora.ru/reqsem.html

5. 5.https: //lex.uz/uz/docs/-417636? query = 